Jiri Bejtkovsky,

Ph.D., Tomas Bata University in Zlin, Czech Republic

\title{
SOCIAL MEDIA PLATFORMS AS HR MARKETING TOOL IN SELECTED HEALTHCARE SERVICE PROVIDERS
}

Abstract. The research paper summarizes the arguments and counterarguments within the scientific discussion on the issue of social media platforms, HR marketing, E-recruitment and human capital management. The primary purpose of the research is to determine whether the size of the selected healthcare providers influences (1) the active use of social media platforms and (2) the creation of the recruitment videos to address potential employees on the internal or external labour market. Systematization literary sources and approaches for solving the problems of the social media platforms, HR marketing, E-recruitment and human capital management indicate that the implementation of IT technologies in the field of human resources management is becoming a necessity in today's world. Regarding methodological tools of the research methods, this research study used quantitative and qualitative marketing research as the essential primary sources of information and data. For the precise questionnaire survey and understanding of the individual questions in the questionnaire, a pretest questionnaire survey was also carried out. The pretest was conducted in the fourth quarter of 2018 on a sample of eight respondents. A significant marketing quantitative research followed after the removal of minor shortcomings, from October 2018 to January 2019. The object of the study was selected healthcare service providers in the Czech Republic. Fifty-eight healthcare service providers were thus analysed. Besides other things, two research hypotheses and one research question were formulated. In the research study, the Pearson's chi-square test, Microsoft Excel 2013 and IBM SPSS Statistics 23 were used to verify the research hypotheses. The research paper presents the results of an empirical analysis showing that (1) there is no statistically significant relationship between the size of the selected healthcare service provider and the active use of the social media platforms as an HR marketing tool; (2) there is a statistically significant relationship between the size of the selected healthcare service provider and the creation of recruiting videos to address potential employees on the internal or external labour market; (3) social media platforms are used for the communication with the patients, clients, public and further for PR or promotion of selected healthcare service provider and the recruitment purposes of human resources and HR marketing. The research also empirically confirms and theoretically proves the need for IT knowledge and the active use of IT technology in the area of human resources management, today in the 21st century. The results of the research can be useful for the domestic and foreign healthcare service providers such as hospitals, maternity hospitals, children's hospitals, hospital wards, field hospitals, nursing homes, asylums, clinics, sanatoriums of long term disease, health resorts, thermal baths, healing spas and other health and medical institutions or for academicians that are interested in human resource management.

Keywords: E-recruitment, healthcare service provider, human capital management, HR marketing, social media platforms.

Introduction. Presently, man is living in the Internet world, in Internet-based technologies and as well consequently web 2.0 communities, where a large number of users interact in real-time and share knowledge or different information. This fact creates opportunities and challenges from group decision making approaches because it involves the large number of users coming from dissimilar backgrounds or/and with different level of information, influence and knowledge (Urena et al., 2019).

Nowadays, modern communication almost exclusively relies on online tools and online technology (Abaido, 2020). In the context of modern IT technologies, social media platforms are a significant and current force in society and the collective beliefs provided in them may define the orientation that community takes (Herrera-Viedma et al., 2017). Regarding this, Mangold and Faulds (2009) inform that social media platforms have an impact on people's buying behaviour, opinions on corporations, products, services and personal attitudes of people, or employees. According to Hammou et al. (2020), the concept of social media represents for experts a lever of great significance since it has

Cite as: Bejtkovsky, J. (2020). Social Media Platforms as HR Marketing Tool in Selected Healthcare Service Providers. Marketing and Management of Innovations, 1, 294-302. http://doi.org/10.21272/mmi.2020.125 
become essential to a successful corporate strategy. However, the recruiting high-quality, loyal, infallible and internally motivated human resources remains a fundamental goal of 21 st-century corporations (Thompson et al., 2008). According to Venclova et al. (2013), human resource knowledge, hard and soft skills are currently considered to be the most valuable resource a corporation has. In this context, Vnouckova et al. (2018) state that employees have become the most significant competitive advantage of corporations and therefore corporations must strive for motivated, talented and loyal human resources and have to build an employer brand. According to Wroblowska (2019), a well-known employer brand has become increasingly significant for success in large and global competition across different segments. In this context, Gavurova et al. (2018) say that the brand of a corporation, product, or service is no longer just what every corporation tells the customer, but also how people, employees, clients or customers perceive the corporation on the market.

HR marketing tools can be used to fulfil this thesis; both in the area of care for existing human resources and in the field of hiring new employees by creating exciting and creative recruitment videos or using social media platforms. This contribution is structured as follows. The first section, Theoretical background, is an overview of the relevant secondary information sources. The second section, Methodology, objective and data, describes the data collection process, the sampling procedure and proposes two research hypotheses and one research question. The following article, Results and discussions, highlights the findings of researches and provides verification of the research hypotheses and answering the research question. This contribution closes with a brief Conclusion section and limitations of the presented researches.

Literature Review. Corporate management needs to discover ways to find the right employees at the right time and using the right recruitment tools, which can currently be social media platforms using Erecruitment or recruiting videos. Besides, corporate management must continually improve access to employee performance to identify their needs and expectations, to improve human relationships and opportunities for education and personal growth as part of internal HR marketing (Hitka et al., 2018).

Social media platforms. Social media platforms are defined as a large, diversified and heterogeneous user base. These platforms can be used not only by individuals but also by corporations for various purposes or various goals (Dong et al., 2018; Herrera-Viedma et al., 2017). One of the characteristics of social media platforms is its ability to reach a large target group in the shortest possible time and send them messages, in most cases at a minimal cost (Ungerman, 2015). According to Scott and Carrington (2011), social media platforms can be considered as platforms where people or groups of people communicate, share information, or meet. Regarding this, Alonso et al. (2013); Perez et al. (2016); Wu et al. (2017) mention that social media platforms allow communication, sharing and exchange of information and for that reason provide social relationships among the persons. During their communication, sharing and exchange of information, decision-makers with more knowledge and experience may influence other decision-makers in the social media platforms. Social media platforms and online-related strategies are convenient for diverse corporate activities, from business to human resource management (Staffileno et al., 2017). Wasserman and Faust (1994) also add that social media platforms allow users from various countries to meet other people or users sharing some of their opinions, interests, and hobbies, and so on. Regarding this, Putzke et al. (2014) claim that over the last few years, social media platforms have become well-known and used. Social media platforms involve applications such as microblogs, blogs, virtual game worlds, social networking sites, content communities, virtual social worlds and collaborative projects (Kaplan and Haenlein, 2011). HR marketing and E-recruitment. Well-adapted HR marketing is today a trend that has a significant impact not only on the corporation's internal environment management but also on its external environment (Urbancova and Hudakova, 2017).

The concept of HR marketing can be defined or perceived as the application of marketing principles and rules in the area of human resource management ( $\mathrm{Ng}$ et al., 2010; Saini et al., 2014). Aggerholm et 
al. (2011) understand the concept of HR marketing as a tool for managing, building, and influencing human resources relationships in a corporation. According to Hitka et al. (2015); Love and Singh (2011), on the one hand, the activities and processes of modern HR marketing focus on contemporary human resources to motivate them, increase the level of their satisfaction and also retain them in the corporation. In this context, Marsikova and Myslivcova (2016) also state that HR marketing tools have a significant impact on the human resources satisfaction and potential employee satisfaction. Regarding this, Archana et al. (2014); Wozniak (2015) claim that on the other hand, HR marketing focuses on potential new human resources entering the corporation, when it is essential to find effective and appropriate opportunities to target and reach a predetermined group of people, and then recruit them for the corporation.

$\mathrm{Ng}$ et al. (2010); Saini et al. (2014) say that the advantages of HR marketing include increasing the competitive ability of the corporation and employees' engagement, reducing the time and financial requirements for the recruitment process or employer brand building. Information technology has a massive influence on all parts of business process, and it is impossible to imagine any of the business aspects that were not, at least in some extends, applied appropriate IT technology (Micic and Radosavac, 2018). According to Anderson (2003); McManus and Ferguson (2003), the development and progress of modern information technology have changed how human resources can be recruited into corporations, and over the last decade there has been a strong trend of recruitment through the Internet, especially among large multinational corporations. Li et al. (2002) say that online recruiting (i.e., E-recruitment) is a primary method for marketing jobs in the labour market. Sceulovs et al. (2017) perceive E-recruitment (web-based recruitment, Internet recruitment or online recruitment) as the process of human resource recruitment exploiting Internet and electronic resources. The focus is one-recruitment as a tool or a process which ensure the corporation's needs for human resources. According to Zusman and Landis (2002), concerning attracting candidates, the Internet plays an essential and irreplaceable role in the electronic recruitment process. Corporations' social media platforms can give candidates with the chance to learn about the corporation (e.g., corporate benefits, values etc.), about the PR activities of the corporation, search for and preview job ads, submit curriculum vitae, watch original and unique recruitment videos and fill out application forms (Lievens et al., 2002).

Methodology and research methods. The contribution focuses on issues related to social media platforms as an HR marketing tool. The research study was done from the point of view of the selected healthcare service providers in the Czech Republic. A primary objective of this article was to investigate whether the size of the selected healthcare service providers influences (1) the active use of the social media platforms and (2) the creation of recruiting videos to address potential employees on the internal or external labour market. In the framework of the research study, secondary and primary information sources were used. The literature review was elaborated using secondary information sources. This information was obtained through scientific monographs, scientific journals and scientific papers from the Web of Science database and the Scopus database. These sources of information dealing with areas of the social media platforms, HR marketing and e-recruitment. The quantitative and qualitative marketing research was used as the principal primary sources of information. The structured questionnaire surveys (the electronic and printed versions) and semi-standardized interviews were used as research techniques. The questionnaire survey respected the anonymity of respondents and the ethical aspect of research. Some results of the research are presented and interpreted in this paper. As a result of the study of scientific information sources, processed literature review and synthesis of information and facts, two research hypotheses $(\mathrm{H} 1$ and $\mathrm{H} 2)$ and one research question (RQ1) were proposed. The hypotheses are formulated as follows:

The research hypothesis $1(\mathrm{H} 1)$ : There is a statistically significant relationship between the size of the selected healthcare service provider and the active use of social media platforms as an HR marketing tool. 
The research hypothesis $2(\mathrm{H} 2)$ : There is a statistically significant relationship between the size of the selected healthcare service provider and the creation of recruiting videos to address potential employees on the internal or external labour market.

The research question $1(\mathrm{RQ} 1)$ is formulated as follows: For what activities using the selected healthcare service providers the social media platforms?

The selected healthcare service providers in the Czech Republic were involved in the research study. This engagement was possible thanks to earlier research cooperation with these healthcare service providers in the Czech Republic. For the precise questionnaire survey and understanding of the individual questions in the questionnaire, a pretest questionnaire survey was also carried out. The pretest was conducted in the fourth quarter of 2018 on a sample of eight respondents significant primarying quantitative research followed after the removal of minor shortcomings, from October 2018 to January 2019. In total, the questionnaire was obtained from fifty-eight respondents. The employees of the selected healthcare service providers in the Czech Republic that are active in and responsible for the area the of human resources (HR employees, HR specialists, HR leaders or HR managers) were confronted with two research hypotheses. The tools of the descriptive statistics (the absolute and relative frequencies) were used for the analysis of the research data. Pearson's statistical method of the Chi-square test was used to verify the defined hypotheses $(\mathrm{H} 1$ and $\mathrm{H} 2)$. Whether there is the dependence between the statistical characters, it determines the Chi-square test. It means that the occurrence of certain A variables may indicate the probability of occurrence of specific $B$ values. The zero hypothesis is rejected if the $p$-value is lower than the chosen significance level (typically 0.05 , i.e. $5 \%$ ). It means that the difference between the abnormalities found in the sample and the expected abundances is too significant to be the result of random selection, i.e. it is statistically significant.

Processing of the research results was performed using a software program Microsoft Excel 2013 and statistical software IBM SPSS Statistics, version 23. The IBM SPSS Statistics software can be described as a high-quality and all-embracing tool for solving different types of statistical problems and mathematical tasks.

Results. In direct connection with the overview of primary scientific literature focusing on social media platforms, HR marketing and e-recruitment, two research hypotheses $(\mathrm{H} 1$ and $\mathrm{H} 2)$ and one research question (RQ1) were developed. The Pearson's chi-square test, Microsoft Excel 2013 and IBM SPSS Statistics 23 were used to verify the research hypotheses. The structure of the selected healthcare service providers according to the number of hospital wards is shown in the table below (Table 1).

Table 1. The structure of the selected healthcare service providers according to the number of the hospital wards

\begin{tabular}{|c|c|c|}
\hline Number of hospital wards (beds) & The absolute frequency $\mathbf{n}$ ) & The relative frequency (\%) \\
\hline $0-99$ & 20 & 34.48 \\
\hline $100-199$ & 9 & 15.52 \\
\hline $200-299$ & 4 & 6.90 \\
\hline $300-399$ & 6 & 10.34 \\
\hline $400-499$ & 2 & 3.45 \\
\hline $500-599$ & 3 & 5.17 \\
\hline $600-699$ & 4 & 6.90 \\
\hline $700-799$ & 1 & 1.72 \\
\hline $800-899$ & 2 & 3.45 \\
\hline $900-999$ & 3 & 5.17 \\
\hline $1000+$ & 4 & 6.90 \\
\hline Total & $\mathbf{5 8}$ & $\mathbf{1 0 0 . 0 0}$ \\
\hline
\end{tabular}

Sources: developed by the author based on own calculations (2019) 
Table 1 presents the structure of the selected healthcare service providers according to the number of hospital wards.

The research hypothesis $1(\mathrm{H} 1)$ : There is a statistically significant relationship between the size of the selected healthcare service provider and the powerful us the social media platforms and HR marketing tool.

$\mathrm{HO}$ : There is no correlation between the size of the selected healthcare service provider and the active use of social media platforms as an HR marketing tool.

The data that characterize the research hypothesis $1(\mathrm{H} 1)$ is presented in table (Table 2).

Table 2. The verification of the research hypotheses H1 using Pearson's Chi-square test $\mathrm{H} 1$ : There is a statistically significant relationship between the size of the selected healthcare service provider and the active use of social media platforms as an HR marketing tool.

\begin{tabular}{|c|c|c|c|}
\hline The statistical method & Chi-square & df & p-value \\
\hline Pearson's Chi-square test & 5.691 & 10 & .840 \\
\hline
\end{tabular}

Sources: developed by the author based on own calculations (2019)

The result of the verification of the research hypothesis $\mathrm{H} 1$ shows that the $\mathrm{p}$-value of Pearson's Chisquare test of independence is 0.840 . The result of its validity verification indicates that the $p$-value of the Pearson's Chi-square test of independence is higher than the specified limit value of 0.05 . Thus, the HO hypothesis is not rejected on the significance level of $5 \%$.

In this case, it can be deduced that there is no statistically significant relationship between the size of the selected healthcare service provider and the active use of social media platforms as an HR marketing tool. The management of the selected healthcare service provider seeks to attract and reach potential employees regardless of whether it is a small, medium or large selected healthcare service, provider.

The research hypothesis $2(\mathrm{H} 2)$ : There is a statistically significant relationship between the size of the selected healthcare service provider and the creation of recruiting videos to address potential employees on the internal or external labour market.

$\mathrm{HO}$ : There is no correlation between the size of the selected healthcare service provider and the creation of recruiting videos to address potential employees on the internal or external labour market.

The table (Table 3) shows data that characterize the research hypothesis $\mathrm{H}$ 2.

Table 3. The verification of the research hypotheses $\mathrm{H} 2$ using Pearson's Chi-square test $\mathrm{H} 2$ : There is a statistically significant relationship between the size of the selected healthcare service provider and the creation of recruiting videos to address potential employees on the internal or external

\begin{tabular}{|c|c|c|c|}
\multicolumn{5}{|c|}{ labour market. } \\
\hline The statistical method & Chi-square & df & p-value \\
\hline Pearson's Chi-square test & 21.534 & 10 & .018 \\
\hline Cramer's V & .609 & Statistical Interpretation & substantial \\
\hline
\end{tabular}

Sources: developed by the author based on own calculations (2019)

When considering the dependence of the relation between the size of the selected healthcare service provider and the creation of recruiting videos to address potential employees on the internal or external labour market, the $p$-value of Pearson's Chi-square test of independence is lower than the defined level of significance $(a=0.05)$.

The result of the verification of the research hypothesis $\mathrm{H} 2$ shows that the null hypothesis $(\mathrm{H} 0)$ of independence was therefore rejected at a level of independence of $5 \%$. The $\mathrm{H} 2$ hypothesis was, therefore, not rejected. 
The research hypothesis $\mathrm{H} 2$ - there is a statistically significant relationship between the size of the selected healthcare service provider and the creation of recruiting videos to address potential employees on the internal or external labour market - was therefore confirmed. According to Cramer's V, it can be concluded that relation is considered as substantial.

The research question $1(\mathrm{RQ} 1)$ : For what activities using the selected healthcare service providers the social media platforms? The addressed respondents said that the social media platforms are used (1) for the communication with the patients, clients, public and further for PR or promotion of selected healthcare service provider, (2) for the recruitment purposes of human resources and HR marketing in their organization (the selected healthcare service provider). No addressed respondent said that they would only have a profile that they do not actively use.

This study gave three essential findings. The first is that there is no statistically significant relationship between the size of the selected healthcare service provider and the active use of social media platforms as an HR marketing tool. That is, the management of the selected healthcare service provider seeks to attract and reach potential employees regardless of whether it is a small, medium or large selected healthcare service, provider. The second important finding is that there is a statistically significant relationship between the size of the selected healthcare service provider and the creation of recruiting videos to address potential employees on the internal or external labour market. Finally, the third finding is that social media platforms are used for the communication with the patients, clients, public and further for PR or promotion of selected healthcare service provider and the recruitment purposes of human resources and HR marketing in their organization (the selected healthcare service provider).

Many research studies analyse E-recruitment in context human resource management, communication or information technology and psychology (Sceulovs, Shatrevich and GaileSarkane, 2017).

According to research findings from Brown (2004), it can be said that the practice of using the Internet to recruit job applicants has increased steadily.

Regarding this, Anderson (2003) says that as many as $90 \%$ of large US corporations are recruiting via the Internet.

HR marketing is effective when human resources participate in their corporation presentations, recruitment campaigns and recruitment videos, which are in line with the research findings of Edwards and Edwards (2013), Elving et al. (2012) or Grabara (2013).

Conclusions. The research paper deals with social media platforms, HR marketing, E-recruitment and human capital management. Nowadays, the field of HR marketing is gaining in importance. The aim of HR marketing is not only existing human resources but also new employees. The tools of external HR marketing can be social media platforms, recruitment videos, PR activities and corporate events.

The research paper was done from the point of view of the selected healthcare service providers in the Czech Republic. A primary objective of this research paper was to investigate whether the size of the selected healthcare service providers influences (1) the active use of the social media platforms and (2) the creation of recruiting videos to address potential employees on the internal or external labour market.

The research paper has a standard structure. The first section, Theoretical background, is an overview of the relevant secondary information sources. These secondary information sources are focused on social media platforms, HR marketing and E-recruitment. Theoretical backgrounds are elaborated through research papers presented mainly in the Scopus database and Web of Science database. The second section, Methodology, objective and data, describes the data collection process, the sampling procedure and proposes two research hypotheses and one research question. The quantitative and qualitative marketing research was used as the essential primary sources of information. The structured questionnaire surveys and semi-standardized interviews were used as research techniques. Some results 
of the research are presented and interpreted in this research paper. In total, the questionnaire was obtained from fifty-eight respondents. The selected healthcare service providers in the Czech Republic were involved in the research paper. The following section, Results and discussions, highlights the findings of researches and provides verification of the research hypotheses and answering the research question. The tools of the descriptive statistics were used for the analysis of the research data. Pearson's statistical method of the Chi-square test was used to verify the defined hypotheses. This research paper provides three significant discoveries. The first discovery is finding that there is no statistically significant relationship between the size of the selected healthcare service provider and the active use of social media platforms as an HR marketing tool. The second discovery is finding that there is a statistically significant relationship between the size of the selected healthcare service provider and the creation of recruiting videos to address potential employees on the internal or external labour market. The third discovery is finding that social media platforms are used for the communication with the patients, clients, public and further for PR or promotion of selected healthcare service provider and the recruitment purposes of human resources and HR marketing in their organization (the selected healthcare service provider). As online jobs are proliferating, there is a unique requirement for further research on social media platforms, Erecruitment and HR marketing (Rozelle and Landis, 2002). It is vital to address many limitations when interpreting the above research findings. First, the research sample was not very large, which may limit the generalizability of research findings. Second, the research sample was geographically limited only to the Czech Republic. Third, the research sample was composed only of employees of the selected healthcare service providers and not all healthcare service providers. Further research in this area could try to ensure a larger research sample size. Nevertheless, this study is among the first to investigate the impact of social media platforms on human resources management in the Czech Republic.

\section{References}

Abaido, G. M. (2020). Cyberbullying on social media platforms among university students in the United Arab Emirates. International Journal of Adolescence and Youth, 25(1), 407-420. [Google Scholar] [CrossRef]

Aggerholm, H. K., Andersen, S. E., \& Thomsen, C. (2011). Conceptualising employer branding in sustainable organisations, Corporate Communications. An International Journal. [Google Scholar] [CrossRef]

Alonso, S., Perez, I. J., Cabrerizo, F. J., \& Herrera-Viedma, E. (2013). A linguistic consensus model for Web 2.0 communities. Applied Soft Computing, 13(1), 149-157. [Google Scholar] [CrossRef]

Anderson, N. (2003). Applicant and recruiter reactions to new technology in selection: A critical review and agenda for future research. International Journal of Selection and Assessment, 11(2-3), 121-136. [Google Scholar] [CrossRef]

Archana, L., Nivya, V. G., \& Thankam, S. M. (2014). Recruitment through social media area: Human Resource. Journal of Business and Management, 1, 37-41.

Brown, D. (2004). Unwanted online jobseekers swamp HR staff. Canadian HR Reporter, 17(7), 1-1.

Dong, Y., Zha, Q., Zhang, H., Kou, G., Fujita, H., Chiclana, F., \& Herrera-Viedma, E. (2018). Consensus reaching in social network group decision making: Research paradigms and challenges. Knowledge-Based Systems, 162, 3-13. [Google Scholar] CrossRef

Edwards, M. R., \& Edwards, T. (2013). Employee responses to changing aspects of the employer brand following a multinational acquisition: a longitudinal study. Human Resource Management, 52(1), 27-54. [Google Scholar] [CrossRef]

Elving, W. J., Westhoff, J. J., Meeusen, K., \& Schoonderbeek, J. W. (2013). The war for talent? The relevance of employer branding in job advertisements for becoming an employer of choice. Journal of Brand Management, 20(5), 355-373. [Google Scholar] [CrossRef

Gavurova, B., Bacik, R., Fedorko, R., \& Nastisin, L. (2018). the customer's brand experience in the light of selected performance indicators in the social media environment. Journal of Competitiveness, 10(2), 72. [Google Scholar] [CrossRef]

Grabara, J. (2013). Employer's expectations towards the employees from the marketing and management department. Polish Journal of Management Studies, 7(1), 58-70. [Google Scholar]

Hammou, I., Aboudou, S., \& Makloul, Y. (2020). Social Media and Intangible Cultural Heritage for Digital Marketing Communication: Case of Marrakech Crafts. Marketing and Management of Innovations, 1, 121-127. [CrossRef]

Herrera-Viedma, E., Cabrerizo, F. J., Chiclana, F., WU, J., Cobo, M. J., \& Samuylov, K. (2017). Consensus in group decision making and social networks. Studies in Informatics and Control, 26(3), 259-268. [Google Scholar] [CrossRef] 
Hitka, M., Balazova, Z., Grazulis, V., \& Lejskova, P. (2018). Differences in employee motivation in selected countries of CEE (Slovakia, Lithuania and the Czech Republic). Inzinerine Ekonomika. [Google Scholar] [CrossRef]

Hitka, M., Stachova, K., Balazova, Z., \& Stacho Z. (2015). Differences in Employee Motivation at Slovak Primary Schools in Rural and Urban Areas. International education studies, 8(5), 33-42. [Google Scholar]

Kaplan, A. M., \& Haenlein, M. (2011). Two hearts in three-quarter time: How to waltz the social media/viral marketing dance. Business horizons, 54(3), 253-263. [Google Scholar] [CrossRef]

Li, C., Charron, C., Roshan, S., \& Flemming, G. N. (2002). Online recruitment grows up. Forrester Research [online]. Retrieved from https://www.forrester.com

Lievens, F., Van Dam, K., \& Anderson, N. (2002). Recent trends and challenges in personnel selection. Personne/ Review, 31(5), 580-601. [Google Scholar] [CrossRef]

Love, L. F., \& Singh, P. (2011). Workplace branding: Leveraging human resources management practices for competitive advantage through «Best Employer» surveys. Journal of Business and Psychology, 26(2), 175. [Google Scholar] [CrossRef] Mangold, W. G., \& Faulds, D. J. (2009). Social media: The new hybrid element of the promotion mix. Business horizons, 52(4), 357-365. [Google Scholar] [CrossRef]

Marsikova, K., \& Myslivcova, S. (2016). Personalni marketing-atributy stabilizace zaměstnanců. Acta academica karviniensia, 16(2), 28-40. [Google Scholar] [CrossRef]

Mcmanus, M. A., \& Ferguson, M. W. (2003). Biodata, personality, and demographic differences of recruits from three sources. International Journal of Selection and Assessment, 11(2-3), 175-183. [Google Scholar] [CrossRef]

Micic L., \& Radosavac V. (2018) Influence of Information Technology to Human Resources Management: Key Trends in 21st Century. In Hadzikadić M., Avdaković S. (eds) Advanced Technologies, Systems, and Applications II. IAT 2017. Lecture Notes in Networks and Systems, 28(1). Springer, Cham.

Ng, E. S., Schweitzer, L., \& Lyons, S. T. (2010). New generation, great expectations: A field study of the millennial generation. Journal of Business and Psychology, 25(2), 281-292. [Google Scholar] [CrossRef]

Perez, L. G., Mata, F., Chiclana, F., Kou, G., \& Herrera-Viedma, E. (2016). Modelling influence in group decision making. Soft Computing, 20(1), 1653-1665. [Google Scholar] [CrossRef]

Putzke, J., Fischbach, K., Schoder, D., \& Gloor, P. A. (2014). Cross-cultural gender differences in the adoption and usage of social media platforms-An exploratory study of Last. FM. Computer Networks, 75(1), 519-530. [Google Scholar] [CrossRef]

Rozelle, A. L., \& Landis, R. S. (2002). An examination of the relationship between use of the Internet as a recruitment source and student attitudes. Computers in Human Behavior, 18(5), 593-604. [Google Scholar] [CrossRef]

Saini, G. K., Rai, P., \& Chaudhary, M. K. (2014). What do best employer surveys reveal about employer branding and intention to apply? Journal of Brand Management, 21(2), 95-111. [Google Scholar] [CrossRef]

Sceulovs, D., Shatrevich, V., \& Gaile-Sarkane, E. (2017). Evaluation of E-recruitment as a Business Model through Internet of Things Approach. Journal of Business and Economics Review (JBER) Vol. 2(1). [Google Scholar]

Scott, J., \& Carrington, P. J. (2011). The SAGE Handbook of social network analysis. London: SAGE Publications.

Staffileno, B. A., Zschunke, J., Weber, M., Gross, L. E., Fogg, L., \& Tangney, C. C. (2017). The feasibility of using facebook, craigslist, and other online strategies to recruit young African American women for a web-based healthy lifestyle behavior change intervention. Journal of Cardiovascular Nursing, 32(4), 365-371. [Google Scholar] [CrossRef]

Thompson, L. F., Braddy, P. W., \& Wuensch, K. L. (2008). E-recruitment and the benefits of organizational web appeal. Computers in Human Behavior, 24(5) 2384-2398. [Google Scholar] [CrossRef]

Ungerman, O. (2015). Social media as a marketing communication tool used by family firms. Acta academica karviniensia, 15(2), 148-162. [Google Scholar] [CrossRef]

Urbancova, H., \& Hudakova, H. (2017). Benefits of employer brand and the supporting trends. Economics and Sociology, 10(4), 41-50. [Google Scholar] [CrossRef]

Urena, R., Chiclana, F., Melancon, G., \& Herrera-Viedma, E. (2019). A social network based approach for consensus achievement in multiperson decision making. Information Fusion, 47(1), 72-87. [Google Scholar] [CrossRef]

Venclova K., Salkova A., \& Kolackova G. (2013). Identification of employee performance appraisal methods in agricultura organizations. Journal of Competitiveness, 05(2). [Google Scholar] [CrossRef]

Vnouckova, L., Urbancova, H., \& Smolova, H. (2018). Building employer image thanks to talent programmes in Czech organisations. Engineering Economics, 29(3), 319-331. [Google Scholar] [CrossRef]

Wasserman, S., \& Faust, K. (1994). Social networks analysis: Methods and Applications (Vol. 8). Cambridge: Cambridge University Press. [Google Scholar]

Wozniak, J. (2015). The use of gamification at different levels of e-recruitment. Management Dynamics in the Knowledge Economy, 3(2), 257-278. [Google Scholar]

Wroblowska, Z. (2019). Personality Requirements for Ukrainian and Czech Managers Creating Brands as a Competitive Advantage. Journal of Competitiveness, 11(1), 152-167. [Google Scholar] [CrossRef]

Wu, J., Chiclana, F., Fujita, H., \& Herrera-Viedma, E. (2017). A visual interaction consensus model for social network group decision making with trust propagation. Knowledge-Based Systems, 122(1), 39-50. [Google Scholar] [CrossRef]

Zusman, R. R., \& Landis, R. S. (2002). Applicant preferences for web-based versus traditional job postings. Computers in Human Behavior, 18(3), 285-296. [Google Scholar] [CrossRef] 
Іржі Бейтковський, Ph.D., Університет Томаша Бата в Зліні (Чеська Республіка).

Соціальні мережі як інструменти HR-маркетингу: на прикладі постачальників медичних послуг

У статті автором систематизовано аргументи та контраргументи в рамках наукової дискусії щодо функціонування соціальних мереж, HR-маркетингу, Е-рекрутингу та управління кадровим потенціалом компанії. Головною метою $є$ аналіз взаємозв'язку між розмірами компаній, що надають медичні послуги та: 1) активністю використання соціальних мереж ними; 2) ефективність промоції послуг через рекрутингове відео адресованого потенційним працівникам на внутрішньому та зовнішньому ринках праці. Систематизація літературних джерел та підходів до специфіки функціонування соціальних мереж, HR-маркетингу, Е-рекрутингу та управління кадровим капіталом засвідчила, що впровадження IT-технологій у процес управління кадровим потенціалом $\epsilon$ невід'ємною складовою. Вихідні данні для дослідження сформовано на основі результатів кількісного та якісного аналізу з використанням методів та інструментів маркетингових досліджень. При цьому дані було доповнено результатами опитування 58 респондентів, що відбувалось у два етапи з метою забезпечення точності та розуміння окремих питань анкети. Кількісне маркетингове дослідження проведено з жовтня 2018 року по січень 2019 року. Об'єктом дослідження стали постачальники медичних послуг у Чеській республіці. У ході дослідження сформовано три наукові гіпотези. Перевірку висунутих гіпотез проведено на основі критерію Пірсона за допомогою програмного забезпечення Microsoft Excel 2013 та IBM SPSS Statistics 23. На основі отриманих результатів у статті зроблено наступні висновки: 1) відсутність статистично значущої залежності між розміром обраного постачальника медичних послуг та а активністю використанням платформ соціальних мереж, як інструменту HR-маркетингу; 2) існує статистично значуща залежність між розміром обраного постачальника медичних послуг та ефективністю промоції послуг через рекрутингове відео; 3) платформи соціальних мереж використовуються для: комунікації з пацієнтами, клієнтами, громадськістю, PR або промоції постачальників медичних послуг, а також рекрутингу та HR-маркетинг. Емпіричні результати дослідження підтверджують необхідність поширення IT в управлінні людськими ресурсами. У свою чергу, отримані результати дослідження можуть бути корисними для вітчизняних та зарубіжних постачальників медичних послуг, для науковців, зацікавлених в управлінні людськими ресурсами.

Ключові слова: е-рекрутинг, постачальник медичних послуг, управління кадровим капіталом, HR-маркетинг, платформи соціальних мереж.

Manuscript received: 24.10.2019.

(C) The author(s) 2020. This article is published with open access at Sumy State University. 